\title{
Development of the School Events Locus of Control Scale
}

\section{KEYWORDS}

education, paedagogy, diagnosis, locus of control, school event, school situation, student, pupil

\begin{abstract}
Many studies have shown that the activity of individuals depends, among others, on constructs such as self-efficacy, self-esteem, motivation, learned helplessness or relations with the environment. They are in turn closely related to the locus of control. As it takes shape under the influence of experiences, past events are important in this process, for students - school events in particular must be taken into account. Due to the fact that tools are missing that could be used by paedagogues to study and diagnose the locus of control of school events in pupils, an attempt has been made to construct it. Existing tools are constructed in other cultures or socio-economic conditions, so this research is an attempt to construct a tool to determine the direction of explaining school events, separately for successes and failures. The sample consisted of 449 second graders from schools above the lower secondary level. The reliability of the tool was verified by the internal compliance coefficient and the validity - by studying the relationship with the chosen variables. The tool can be considered validated. In terms of the failures scale, the tool achieved satisfactory reliability, while the in terms of the scale of success - it needs more development.
\end{abstract}

Adam Mickiewicz University Press, pp. 247-265

ISSN 2300-0422. DOI 10.14746/kse.2019.15.16

ORCID: https://orcid.org/0000-0003-4464-4214

\section{Introduction}

Intense changes taking place on the job market had caused the redefinition of strategic objectives described for education systems. Particular pressure was put on equipping learners with key competences enabling life-long learning (Organisa- 
tion for Economic Cooperation and Development, 2008). The efficacy of the learning process depends on traits of personality, on attitudes and convictions.

Studies indicate significant influence of the locus of control on the functioning of people within self-education. Persons with a feeling of internal control of events are more active and better motivated (Weiner, 1985). Hence, it is important to shape within youths the conviction that they are able to influence the results of their actions.

Organising effective educational activities should take into account a reliable diagnosis of pupils' convictions. The available questionnaires that are used to measure the locus of control, constructed under different cultural conditions and having unsatisfactory psychometric properties, substantiate the need to construct a new tool that could be used in daily educatin practice.

\section{The concept of the locus of control and its significance for explaining behaviour}

The Locus of Control (LOC) is a relevantly permanent character property of man, constituting a generalised expectation concerning subjectively experienced location of the influence of events. According to the social learning theory of Julian B. Rotter, throughout their lives people learn to believe that they are in control of their fate or that it is controlled by factors that are independent of them (Drwal, 1995). This permits the delineation between persons with a feeling of internal control, meaning, those that are convinced that events depend on their behaviour, and those with a feeling of external control - convinced that the results of behaviour are outside of their sphere of influence - and depend on fate, destiny, on others (Rotter, 1966).

Many studies indicate the decisive role of past experiences in the emergence of the perception of control (Bandura, 1977; Rotter, 1966; Seligman, 1984). Theories of attribution divide causal factors into personal and environmental ones. As a result of the repetition of a sequence of events, expectations solidify and can be treated as a fairly durable property of personality (Drwal, 1995; Forsterling, 2005; Krasowicz and Kurzyp-Wojnarska, 1990; Wong and Weiner 1981).

According to the achievement theory of motivation, human behaviour is determined by the expectation of future success within a specific person, its value for the individual and the motivation to strive for success or to avoid failure. Only after the event, people analyse the relevant causes and the, and the response aims their later behaviour (Weiner, 1985). This means that to see one's influence on 
the causes of events has significant meaning for the expectation of success in the future, meaning, it shapes motivation, shining through in the positive correlation between the internal LOC and motivation.

Additionally, the feeling of control is closely related to perceived self-efficacy, hence, the conviction of people that they are able to achieve goals that are important for them. According to the social learning theory, human behaviour is driven by expectations concerning: situations, results of actions and self-efficacy. The feeling of self-efficacy concerns the action itself and forms a part of the scope of control of personal activity. Studies confirm this relation and the positive correlation of efficacy with the internal locus of control (Bandura, 1997).

As a result of the feeling of inability to control events (meaning, the external LOC), learned helplessness emerges. (Meier and Seligman, 1976). The attributive model of learned helplessness permits one to expect that a higher level of learned helplessness shall be the case in persons with an internal locus of control for failures, and an external one - for successes (Abramson et al., 1978).

It was also shown that persons with an internal locus of control, thanks to the fact that they believe that they have influence on the world that surrounds them, exhibit higher self-acceptance and self-esteem, and thanks to this, become better emotionally and socially adapted. According to Morris Rosenberg, self-esteem is the attitude towards the I, a type of global assessment of one's self (positive or negative). A high global self-esteem describes the conviction that one is a sufficiently good, valuable person, whereby low self-esteem means dissatisfaction with oneself, the rejection of one's own I (Rosenberg, 1965, from: Dzwonkowska et al., 2007). As a literature overview shows (Baumaister et al., 2003), persons having high self-esteem see themselves in a better light, as a result of the conviction of controllability of their own lives (meaning, the internal locus of control).

The feeling of loneliness is a subjective assessment of the fact that the number of relations or their quality is lower than desired by an individual (Dykstra et al., 2012). This is why persons having an external LOC, who have the feeling that what is happening in their lives is the result of other people's actions, do not make close and heartfelt relations with others or are not satisfied with the relations that they already made. This is confirmed by the positive correlation between the feeling of loneliness and the external locus of control and between satisfaction with interpersonal relations and the internal LOC (Hojat, 1982; Yinghua and Lin, 2015).

Persons with an external LOC are more persistent when solving puzzles and experimental tasks (Crandall et al., 1965), they devote more time to home chores (Rotter, 1966), have higher self-esteem (Nowicki and Strickland, 1973) and a more real image of themselves (Maqsud, 1980), they are able to delay gratification thanks 
to their conviction of the ability to achieve more valuable rewards even if they are delayed in time (Drwal, 1978).

Studies (Skinner, Zimmer-Gembeck, Connell, Eccles and Wellborn, 1998; Klein and Wasserstein-Warnet, 2000) indicate the possibility of shifting the locus of control, and the school, as an institution ran by professionals, is able to change harmful convictions and to support behaviour enabling effective functioning both in the school environment, outside of it, as well as in the future, in professional life.

\section{Tools to measure the LOC}

Below is a short description of selected tools used to measure the LOC.

According to the idea of the generalised feeling of control, many tools used to measure this property treats as being unidimensional, meaning, it fuses the convictions of the studied individuals referred to various spheres of life.

A popular tool to measure the LOC is the Rotter scale meant for adults (Internal-External Control Scale; I-E) with reliability measured by Cronbach's $\alpha$ at 0.69-0.73 (Rotter, 1966). In the original version, on the basis of factorial analyses, the LOC was treated as a unidimensional construct. However, later analyses of the I-E scale had shown that the locus of control measured using this scale is not unidimensional (Drwal, 1995).

Unifactorial is also the tool developed by Stephen Nowicki and Bonnie R. Strickland. It was constructed in three versions for various age groups ( $<9$ years; $9-18 ; 18<$ ). Every scale applies to a generalised locus of control. The reliability of estimation using the split-half method for forms 3-5: $r=0.63$, for forms 6-8: $\mathrm{r}=$ 0.68 , for forms 9-11: $\mathrm{r}=0.74$ and for pupils from form 12: $\mathrm{r}=0.81$ (Nowicki and Strickland, 1973).

The Polish unifactorial test is the Delta questionnaire. The reliability of the test was estimated by various methods using various samples. In a group of students, estimates by way of the test-retest method yielded results ranging from 0.38 to 0.79 , however, using the split half equivalence method -0.68 . The internal consistency of the questionnaire in a group of pupils at a juvenile detention centre was at Cronbach's $\alpha=0.69$, and in the group of pupils of upper secondary schools - Cronbach's $\alpha=0.83$ (Drwal, 1995).

A popular test to measure the LOC in children and youths (forms 3-12) is the Intellectual Achievement Responsibility (IAR) Questionnaire by Virginia Crandall et al. (1965). Beside the general result showing the locus of control it differentiates 
between subscales for successes (I+) and failures (I-). Reliability measured using the split-half method for the pupil sample was between 0.54 and 0.60 .

A Polish questionnaire, meaning, the Kwestionariusz do Badania Poczucia Kontroli (Questionnaire studying the Locus of Control) for youths aged 13-17 tests the LOC in four areas: school, peer group, parents and others. The test reliability measured using Cronbach's $\alpha$ internal consistency for failures $=0.54$, for successes 0.40 , and for the entire scale 0.62 . It was created in the year 1983 on the basis of studies from the year 1981 (Krasowicz and Kurzyp-Wojnarska, 1990).

The revised Polish version of the tool consists of 43 items, of which 38 are diagnostic ones ( 15 success subscale, 10 failure subscale and 13 not qualified within any subscale). The tool, similarly to its original version, refers to four spheres of life: school (14 items), parents (nine items), friends (seven items) and "unspecified" (nine items). The reliability of the revised version of the questionnaire (Krasowicz-Kupis and Wojnarska, 2017) was for the general result 0.80 (girls) and 0.86 (boys), and for the subscales: success -0.63 , failure -0.64 . The authors do not indicate the reliability for the individual spheres of life, however, due to the number of questions in the spheres and the properties of Cronbach's internal consistency coefficient, one may judge that the reliability of detailed scales is lower than the subscales of failures and successes.

Taking into account that the majority of existing tools was constructed in different cultures or socio-economic conditions, and the newest Polish tool assumes values of $\alpha$ only permitting studies and diagnosis at the highest level of aggregation, an attempt was made to construct a new tool that would be useful in the daily work of the paedagogue, to test the feeling of the locus of control in situations specific for pupils, meaning - events taking place at school.

\section{Method}

The study ${ }^{1}$ saw the participation of 506 pupils (of which $45.0 \%$ were girls) of second form in upper secondary schools of Bydgoszcz, Poland, aged 17-19, written basis for the drawing was data from the municipal teacher's education facility (Pl. Miejski Ośrodek Edukacji Nauczycieli) spanning upper secondary schools operated in the area of the city of Bydgoszcz and the forms at these schools. The sample was taken selecting three layers (school type: general education upper secondary

\footnotetext{
${ }^{1}$ Badanie zostało przeprowadzone pod kierownictwem Barbary Ciżkowicz, przy współpracy z Miejskim Ośrodkiem Edukacji Nauczycieli w Bydgoszczy w I kwartale 2015r.
} 
school, technical school, vocational school). In every layer, schools were drawn, after which classes were drawn. However, not everyone would answer correctly (e. g. they would not select any answers to a question or would select two different ones). In the end, analysed were responses of 449 persons (214 from general schools, 169 from technical schools and 66 from vocational schools), where the proportion of correct responses exceeded 80.

Pupils filled in standardised psychological questions concerning their own efficacy, self-esteem, feeling of loneliness, school helplessness, motivation, as well as a questionnaire to measure the locus of control in school situations, constructed for the study.

The feeling of efficacy was tested with the General Self-Efficacy Scale (GSES) as adapted by Juczyński (2001; Schwarzer, 1998). It measures the power of the general conviction of an individual about the efficacy of coping with difficult situations and obstacles. Its reliability measured using Cronbach's alpha is 0.84 . The tool is composed of ten statements making up a single factor, to which the studied individuals were to provide responses on a four-grade scale of estimation. The empirical coefficient of the feeling of efficacy takes values between 10 and 40 , whereas the higher the result, the higher the feeling of self-efficacy of the tested person.

The Feeling of loneliness was measured using the De Jong Gierveld Loneliness Scale (DJGLS) in the Polish adaptation by Grygiel et al. (2013). It is composed of 11 statements concerning interpersonal relations. The tested persons would express their opinion on the statements using a five-grade scale of estimation. Hence, the result is found in the range between 11 and 55 points, whereby the higher the result on the scale, the relations are worse in view of the tested persons. The internal consistency of the scale items is high (Cronbach's alpha $=0.89$ ).

The measurement of self-esteem used the Rosenberg Self-Esteem Scale (SES) in the Polish adaptation by Dzwonkowska et al. (2007). It is composed of ten statements analysing the positive or negative attitude towards the self, being a type of global evaluation of oneself. The tested persons would indicate the level of agreement with a specific statement on a four-grade scale. The higher the result, in the range between 10 and 40, the higher the self-esteem. The internal consistency of the scale items is high (Cronbach's $\alpha=0.84$ ).

The feeling of helplessness was measured using the School Helplessness Scale (Pl. Skala Bezradności Szkolnej, SBS) by Ciżkowicz (2009). Reliability of measurement estimated using the internal consistency method is high (Cronbach's $\alpha$ $=0.84$ ). The scale is composed of 20 items describing behaviour related to participation in classes. The tested persons would estimate, how frequently they occur, 
by providing answers ranging from „never” (encoded as 1) to „always” (5). The helplessness coefficient takes the value of 20-100 points. The higher the result, the more intense the helplessness.

The motivation to learm was tested using the Statistics Learning Scale (Pl. Skala do Uczenia się Statystyki) (Ciżkowicz, 1999). It is composed of 38 items, to which the tested persons would express their responses using the five-point Likert scale (1-5). As a result, the level of motivation to learn may have a value between 38 and 190 , whereby the higher the result, the higher the motivation to learn. The reliability of the scale is estimated to be 0.91 .

\section{The scale of the locus of control for school events}

In course of construction of the tool, considered were historic studies, in which factorial analyses indicated that with respect to various spheres of life, people utilise different explanations. As the tool was constructed in order to be used to execute a possible diagnosis of the locus of control in school conditions, attention was paid to the most frequent school-related events, meaning, situations that a pupil experiences during their learning that are directly related to the school environment.

Another significant aspect when developing the tool was the fact that people perceive and explain situations differently depending on whether the result of the event is positive or negative (Abramson et al., 1978, Crandall et al., 1965). For this reason, the questionnaire is made up of two subscales: locus of control for successes and failures.

The first version of the questionnaire was composed of 20 sentences describing school situations (10 positive and 10 negative events), constructed conditionally, e. g. as: „if... (event description, e. g. „If I did not understand the lesson"), then in most cases because:". Every sentence is concluded with two answers, e. g. an internal explanation (meaning, if the cause of the event was related to actions or properties of the pupil, e. g. „I didn't listen attentively enough”) and an external one (if the event took place as a result of actions of others or of circumstances, e. g. "the teacher did not explain it well”). The mode of explanation (internal or external) is marked as $\mathbf{A}$ or $\mathbf{B}$ (the letter assignments were random). The pupils could choose, which cause takes place more frequently in their opinion, by marking responses as "A much more often”, „A more often”, „B more often”, „B much more often” and „don't know”. An example question would look like this: 


\begin{tabular}{|l|l|l|l|l|l|l|}
\hline \multicolumn{7}{|c|}{ 1. If I did not understand the lesson, then in most cases because: } \\
\hline $\begin{array}{l}\text { A: } \\
\begin{array}{l}\text { I didn't } \\
\text { listen } \\
\text { attentively } \\
\text { enough }\end{array}\end{array}$ & $\begin{array}{l}\text { A much } \\
\text { more often }\end{array}$ & $\begin{array}{l}\text { A more } \\
\text { often }\end{array}$ & don't know & $\begin{array}{l}\text { B more } \\
\text { often }\end{array}$ & $\begin{array}{l}\text { B much } \\
\text { more often }\end{array}$ & $\begin{array}{l}\text { B: } \\
\text { the teacher } \\
\text { did not } \\
\text { explain it } \\
\text { well }\end{array}$ \\
\cline { 2 - 7 }
\end{tabular}

Responses of the pupils were coded ranging from 1 (most external explanation of the causes of the event) to 5 (most internal explanation of the causes of the event). The mean score for the items for failures or successes is accordingly the empirical factor of the locus of control of failures or successes.

The fundamental criteria that research tools in social sciences must fulfil are reliability and validity (Brzeziński, 2004).

Reliability, referred to as the level, to which test results may be assigned to the influence of systematic variance sources (APA, 2007), was estimated using a method based on an analysis of the properties of test items (Brzeziński, 2004), on the basis of Cronbach's a reliability scale (1951). The reliability analysis was conducted separately for the subscales of failures and successes.

Table 1. Results of the analysis of reliability of the failure subscale

\begin{tabular}{|c|c|c|c|c|}
\hline \multirow[t]{2}{*}{ question } & \multicolumn{2}{|c|}{ all items factored in } & \multicolumn{2}{|c|}{$\begin{array}{l}\text { items selected on the } \\
\text { basis of the Cronbach's } \\
\text { alpha reliability coeffi- } \\
\text { cient factored in }\end{array}$} \\
\hline & $\mathrm{r}$ & $\alpha$ & $\mathrm{r}$ & a \\
\hline $\begin{array}{l}\text { 1P If I did not understand the lesson, then in most } \\
\text { cases because: } \\
\text { A: I didn't listen attentively enough } \\
\text { B: the teacher did not explain it well }\end{array}$ & 0.46 & 0.61 & 0.43 & 0.64 \\
\hline $\begin{array}{l}\text { 3P If I do bad on a test, then in most cases because: } \\
\text { A: it was too difficult } \\
\text { B: I didn't prepare well enough for it }\end{array}$ & 0.42 & 0.62 & 0.46 & 0.63 \\
\hline $\begin{array}{l}\text { 4P If I did not know the response to a question the } \\
\text { teacher asked, then in most cases because: } \\
\text { A: I did not pay attention in class } \\
\text { B: it was too difficult }\end{array}$ & 0.41 & 0.62 & 0.40 & 0.65 \\
\hline $\begin{array}{l}\text { 6P If I am late for classes, then in most cases be- } \\
\text { cause: } \\
\text { A: I left home too late } \\
\text { B: my bus got away }\end{array}$ & 0.22 & 0.66 & $\mathrm{x}$ & $\mathrm{x}$ \\
\hline
\end{tabular}




\begin{tabular}{|c|c|c|c|c|}
\hline $\begin{array}{l}8 \mathrm{P} \text { If the teacher admonished me, then in most } \\
\text { cases because: } \\
\text { A: they do not like me } \\
\text { B: I did not behave like I should have }\end{array}$ & 0.25 & 0.65 & 0.28 & 0.68 \\
\hline $\begin{array}{l}\text { 13P If I had not done my homework, then in most } \\
\text { cases because: } \\
\text { A: I had more important things to do } \\
\text { B: there was no time for it }\end{array}$ & 0.16 & 0.67 & $\mathrm{x}$ & $\mathrm{x}$ \\
\hline $\begin{array}{l}15 \mathrm{P} \text { If I got a bad mark, then in most cases because: } \\
\text { A: the teacher was unjust } \\
\text { B: I wasn't prepared well enough }\end{array}$ & 0.38 & 0.63 & 0.44 & 0.64 \\
\hline $\begin{array}{l}16 \mathrm{P} \text { If a project that I participated in failed, then in } \\
\text { most cases because: } \\
\text { A: I did not fit in with the work of the group } \\
\text { B: other members of the project team did not do } \\
\text { what they should have done }\end{array}$ & 0.16 & 0.67 & $\mathrm{x}$ & $\mathrm{x}$ \\
\hline $\begin{array}{l}18 \mathrm{P} \text { If I did not do an exercise right, then in most } \\
\text { cases because: } \\
\text { A: I did not listen to the teacher's explanation at- } \\
\text { tentively enough } \\
\text { B: the teacher did not explain the exercise in } \\
\text { a manner that was understandable to me }\end{array}$ & 0.38 & 0.63 & 0.35 & 0.66 \\
\hline $\begin{array}{l}20 \mathrm{P} \text { If I did not remember the material, then in } \\
\text { most cases because: } \\
\text { A: it was too complex } \\
\text { B: I didn't devote enough time to it }\end{array}$ & 0.41 & 0.62 & 0.42 & 0.65 \\
\hline Cronbach's alpha of the subscale & \multicolumn{2}{|c|}{0.66} & \multicolumn{2}{|c|}{0.72} \\
\hline Spearman-Brown coefficient & \multicolumn{2}{|c|}{0.67} & \multicolumn{2}{|c|}{0.71} \\
\hline
\end{tabular}

$\mathrm{r}$ - correlation between the item and the rest of the scale,

$\alpha$ - Cronbach's $\alpha$ reliability coefficient after that item is removed from the scale

Source: Own work

Table 2. Results of the analysis of reliability of the success subscale

\begin{tabular}{|c|c|c|c|c|}
\hline \multirow[t]{2}{*}{ question } & \multicolumn{2}{|c|}{ all items factored in } & \multicolumn{2}{|c|}{$\begin{array}{l}\text { items selected on the } \\
\text { basis of the Cronbach's } \\
\text { alpha reliability coeffi- } \\
\text { cient factored in }\end{array}$} \\
\hline & $\mathrm{r}$ & $a$ & $\mathrm{r}$ & $\alpha$ \\
\hline $\begin{array}{l}2 S \text { If I was active in class, then in most cases be- } \\
\text { cause: } \\
\text { A: the lessons were interesting } \\
\text { B: I knew the answers to the questions }\end{array}$ & 0.04 & 0.34 & $\mathrm{x}$ & $\mathrm{x}$ \\
\hline
\end{tabular}




\begin{tabular}{|c|c|c|c|c|}
\hline $\begin{array}{l}5 S \text { If the teacher praised me, then in most cases } \\
\text { because: } \\
\text { A: he just liked me } \\
\text { B: I deserved the praise }\end{array}$ & 0.16 & 0.28 & 0.24 & 0.49 \\
\hline $\begin{array}{l}\text { 7S If I remembered the material fro class well, then } \\
\text { in most cases because: } \\
\text { A: I listened attentively and understood a lot } \\
\text { B: the teacher explained it well }\end{array}$ & 0.03 & 0.34 & $\mathrm{x}$ & $\mathrm{x}$ \\
\hline $\begin{array}{l}9 S \text { If it was easy for me to do the exercises in class, } \\
\text { then in most cases because: } \\
\text { A: I paid attention and thus I knew how to do it } \\
\text { B: they were easy }\end{array}$ & 0.09 & 0.31 & $\mathrm{x}$ & $\mathrm{x}$ \\
\hline $\begin{array}{l}\text { 10S If I got a good mark, then in most cases be- } \\
\text { cause: } \\
\text { A: I was lucky } \\
\text { B: I studied }\end{array}$ & 0.25 & 0.24 & 0.34 & 0.42 \\
\hline $\begin{array}{l}\text { 11S If an undertaking succeeded that I took part } \\
\text { in, then in most cases because: } \\
\text { A: others did what was supposed to be done } \\
\text { B: the entire team worked effectively }\end{array}$ & 0.12 & 0.29 & 0.27 & 0.47 \\
\hline $\begin{array}{l}12 S \text { If I responded to the teacher's question cor- } \\
\text { rectly, then in most cases because: } \\
\text { A: I made it } \\
\text { B: my knowledge was sufficient }\end{array}$ & 0.29 & 0.22 & 0.38 & 0.40 \\
\hline $\begin{array}{l}\text { 14S If I understood a concept correctly, then in } \\
\text { most cases because: } \\
\text { A: it aligns with my interests } \\
\text { B: I amended my knowledge of my own accord }\end{array}$ & 0.11 & 0.30 & $\mathrm{x}$ & $\mathrm{x}$ \\
\hline $\begin{array}{l}17 \mathrm{~S} \text { If a friend asked me for help, then in most cas- } \\
\text { es because: } \\
\text { A: learning together is more effective } \\
\text { B: they know that I am able to help them }\end{array}$ & 0.18 & 0.27 & 0.20 & 0.51 \\
\hline $\begin{array}{l}19 S \text { If I solved an exercise correctly, then in most } \\
\text { cases because: } \\
\text { A: it was explained well by the teacher } \\
\text { B: I prepared for it ahead of time }\end{array}$ & -0.04 & 0.37 & $\mathrm{x}$ & $\mathrm{x}$ \\
\hline Cronbach's alpha of the subscale & \multicolumn{2}{|c|}{0.32} & \multicolumn{2}{|c|}{0.55} \\
\hline Spearman-Brown coefficient & \multicolumn{2}{|c|}{0.36} & \multicolumn{2}{|c|}{0.51} \\
\hline
\end{tabular}

$r$ - correlation between the item and the rest of the scale,

$a$-Cronbach's $\alpha$ reliability coefficient after that item is removed from the scale

Source: Own work 
As result of the analysis of the differentiating power of the scale items (table 1 for the failure subscale and table 2 for the success subscale), three questions were rejescted for the failure subscale and five questions were rejected for the failure subscale. The value of Cronbach's alpha for failures (seven items) was 0.72 , and for successes (five items) - 0.55. This means that the success subscale needs more work and must be reanalysed.

Cronbach's alpha internal consistency coefficient for the entire tool is 0.81 , and the Spearman-Brown coefficient - 0.78.

In order to verify the conducted analysis and selection of the best test items, an exploratory factorial analysis was conducted (Zakrzewska, 1994). The fulfilment of assumptions of the use of reduction of data by way of a factorial analysis was confirmed by Bartlett's test $\left(\chi^{2}=921.86, \mathrm{df}=190, \mathrm{p}<0.01\right)$ and the Kaiser-Meyer-Olkin index (0.734). On the basis of these results, the hypothesis can be rejected that the matrix of correlation coefficients is an identity matrix, and conclude that the expected reduction is significant, indicating the execution of the analysis was substantiated.

Factors were discerned using the varimax rotation method. On the basis of Kaiser's criterion, two factors were discerned that, when all items are factored in, explain $65 \%$ of the total variance (first scale $-37 \%$, second scale $-28 \%$ ), whereby when items are considered as selected on the basis of Cronbach's alpha reliability coefficient they explain $72 \%$ of the total variance (first scale $-41 \%$, second scale $-31 \%$ ).

When all items in the questionnaire are taken into account, eight of them (PK2, PK6, PK7, PK9, PK13, PK14, PK19), those, the removal of which from the scale was related to an increase of Cronbach's alpha, did not sufficiently load any of the factors (above 0.4). This confirmed the necessity of removal of these items from the scale. One item (PK 15) more strongly loaded the factor that was opposed to its scale. Taking into account solely the items indicated in the scale, all items load the factor loaded by other questions from the same subscale. This confirms both the justification of inclusion of these questions in the tool as well as the subdivision into the subscales of failures and successes.

Table 3. Factorial load values

\begin{tabular}{|l|c|c|c|c|c|}
\hline \multirow{2}{*}{ QUESTION NO. } & \multirow{2}{*}{$\begin{array}{c}\text { FAILURE / } \\
\text { SUCCESS }\end{array}$} & \multicolumn{2}{|c|}{ all items factored in } & \multicolumn{2}{|c|}{$\begin{array}{c}\text { items selected on the basis of } \\
\text { the Cronbach's alpha reliability } \\
\text { coefficient factored in }\end{array}$} \\
\cline { 3 - 6 } & & FACTOR 1 & FACTOR 2 & FACTOR 1 & FACTOR 2 \\
\hline PK1 & F & 0.06 & $\mathbf{0 . 6 9}$ & $\mathbf{0 . 6 8}$ & -0.19 \\
\hline PK2 & S & -0.08 & -0.11 & & 0.16 \\
\hline PK3 & F & 0.35 & $\mathbf{0 . 4 9}$ & $\mathbf{0 . 6 3}$ & \\
\hline
\end{tabular}




\begin{tabular}{|c|c|c|c|c|c|}
\hline PK4 & $\mathrm{F}$ & 0.24 & 0.52 & 0.61 & 0.006 \\
\hline PK5 & S & 0.45 & -0.08 & 0.05 & 0.45 \\
\hline PK6 & $\mathrm{F}$ & -0.06 & 0.39 & & \\
\hline PK7 & $S$ & -0.11 & 0.24 & & \\
\hline PK8 & $\mathrm{F}$ & 0.35 & 0.46 & 0.44 & 0.21 \\
\hline PK9 & S & 0.37 & 0.08 & & \\
\hline PK10 & S & 0.52 & -0.25 & -0.07 & 0.63 \\
\hline PK11 & $S$ & 0.52 & -0.09 & 0.06 & 0.55 \\
\hline PK12 & S & 0.52 & -0.19 & -0.01 & 0.61 \\
\hline PK13 & $\mathrm{F}$ & -0.04 & 0.32 & & \\
\hline PK14 & S & 0.08 & -0.15 & & \\
\hline PK15 & $\mathrm{F}$ & 0.61 & 0.33 & 0.53 & 0.46 \\
\hline PK16 & $\mathrm{F}$ & -0.217 & 0.41 & & \\
\hline PK17 & $S$ & 0.42 & -0.21 & -0.05 & 0.48 \\
\hline PK18 & $\mathrm{F}$ & $<0.001$ & 0.63 & 0.61 & -0.22 \\
\hline PK19 & $S$ & -0.33 & -0.09 & & \\
\hline PK20 & $\mathrm{F}$ & 0.34 & 0.5 & 0.59 & 0.18 \\
\hline
\end{tabular}

Source: Own work

The validity of a tool allows one to determine, just how faithfully do the measurement factors reflect the studied property (APA, 2007). On the basis of subject literature, it may be expected that persons with an internal LOC will be characterised by high global self-esteem (SES) and motivation to learn (MOTIV), high self-efficacy index (GSES) and low helplessness (SBS) and low loneliness (DJGLS) levels.

Table 4 lists the descriptive statistics for all quantitative variables included in the analyses as well as the values of the Shapiro-Wilk test.

Table 4. Descriptive statistics and values of the Shapiro-Wilk test $(\mathrm{N}=449)$

\begin{tabular}{|l|c|c|c|c|c|c|}
\hline \multicolumn{1}{|c|}{ Variables } & $\mathrm{M}$ & $\mathrm{SD}$ & Min. & Max. & $\mathrm{W}$ & $\mathrm{p}$ \\
\hline LOC failures & 3.2 & 0.71 & 1.0 & 5.0 & 0.990 & 0.005 \\
\hline LOC successes & 3.7 & 0.67 & 1.4 & 5.0 & 0.979 & $<0.001$ \\
\hline DJGLS & 23.6 & 8.25 & 11 & 52 & 0.959 & $<0.001$ \\
\hline GSES & 30.3 & 4.65 & 10 & 40 & 0.981 & $<0.001$ \\
\hline SES & 29.7 & 6.00 & 10 & 40 & 0.977 & $<0.001$ \\
\hline SBS & 53.3 & 10.29 & 24 & 87 & 0.996 & 0.356 \\
\hline MOTIV & 125.4 & 19.56 & 57 & 179 & 0.992 & 0.016 \\
\hline
\end{tabular}

Source: Own work 
The validity analysis was conducted in two ways: by verifying the relationship of the analysed variable and criterion variables and by differentiating of the level of criterion variables by the analysed variable. As almost all of the analysed variables (save for helplessness) were characterised by distribution strongly different than normal (conf. tab. 4), the validity analysis used non-parametric tests (Spearman's Rank correlation and the Mann-Whitney U test).

The average result on the failures scale (conf. tab. 4) was lower than for the success scale (meaning, more strongly aimed at the outside).

In tasks concerning successes, only $20.5 \%$ of those studied (that is, 92 persons) found themselves in the group with external LOC, and 79.5 (357 persons) with internal LOC. In tasks concerning failures, 182 people (or $40.5 \%$ of those studied) explained them by external causes.

In order to confirm criterion validity, correlations were calculated between the individual variables (tab. 5)

Table 5. Values of Spearman's Rank correlation coefficient

\begin{tabular}{|c|c|c|c|c|c|c|}
\hline Variables & $\begin{array}{c}\text { LOC } \\
\text { successes }\end{array}$ & DJGLS & GSES & SES & SBS & MOTIV \\
\hline LOC failures & $0.12^{\star}$ & $-0.14^{\star *}$ & 0.04 & 0.06 & -0.09 & $0.12^{\star *}$ \\
\hline LOC successes & 1.00 & -0.04 & $0.17^{\star * *}$ & $0.12^{*}$ & $-0.33^{* * *}$ & $0.51^{\star * *}$ \\
\hline DJGLS & & 1.00 & $-0.34^{* * *}$ & $-0.47^{* * *}$ & $0.26^{\star * *}$ & $-0.10^{*}$ \\
\hline GSES & & & 1.00 & $0.51^{\star * *}$ & $-0.39^{* * *}$ & $0.24^{* * *}$ \\
\hline SES & & & & 1.00 & $-0.45^{\star * *}$ & $0.19^{* * *}$ \\
\hline SBS & & & & & 1.00 & $-0.61^{\star * *}$ \\
\hline
\end{tabular}

Source: Own work

The above results show that the more internal explanation of failures, the less lonely and better motivated do people feel. And the more they ascribe successes to themselves, the more efficient they are and the better they perceive themselves, are more strongly motivated and less helpless. The directions of relations between the variables are thus aligned with expectations.

Tests of criterion validity were additionally conducted checking, whether criterion variables differ in groups characterised by internal and external LOC. For this reason, the LOC variable was dichotomised (both for failures as well as successes), with the value being the mean point score achieved for items dealing with failures or successes. As the division criterion the value of three was assumed, in line with the assumed response scale: the tested subjects who achieved a score below 3 were classified as having an external LOC (182 persons for failures and 92 persons for 
successes), and persons with scores above 3 - as having an internal LOC in that area (267 persons for failures and 357 for the success scale), there were no people who would have a result equal to 3 .

The analysis of differences in the levels of criterion variables between persons with an internal and an external LOC was conducted using the Mann-Whitney U test (tab. 6 and 7).

Table 6. Direction of explanation of failures and criterion variables

\begin{tabular}{|c|c|c|c|c|c|c|c|c|c|}
\hline variable & $\begin{array}{c}\text { LOC } \\
\text { failures }\end{array}$ & $\mathrm{N}$ & $\mathrm{Me}$ & M & SD & $\begin{array}{c}\text { rank } \\
\text { average }\end{array}$ & $\mathrm{U}$ & $\mathrm{Z}$ & $\mathrm{p}$ \\
\hline \multirow{2}{*}{ DJGLS } & ext & 182 & 24 & 25.2 & 9.20 & 203.34 & \multirow{2}{*}{20354} & \multirow{2}{*}{-2.92} & \multirow{2}{*}{0.003} \\
\hline & int & 267 & 21 & 22.4 & 7.34 & 239.77 & & & \\
\hline \multirow{2}{*}{ GSES } & ext & 182 & 30 & 30.0 & 5.21 & 220.30 & \multirow{2}{*}{23441} & \multirow{2}{*}{-0.64} & \multirow{2}{*}{0.525} \\
\hline & int & 267 & 30 & 30.5 & 4.21 & 228.21 & & & \\
\hline \multirow{2}{*}{ SES } & ext & 182 & 29 & 28.9 & 6.43 & 209.74 & \multirow{2}{*}{21519.5} & \multirow{2}{*}{-2.06} & \multirow{2}{*}{0.039} \\
\hline & int & 267 & 31 & 30.1 & 5.64 & 235.40 & & & \\
\hline \multirow{2}{*}{ SBS } & ext & 182 & 54 & 54.7 & 10.60 & 239.81 & \multirow{2}{*}{21601} & \multirow{2}{*}{-2.00} & \multirow{2}{*}{0.046} \\
\hline & int & 267 & 52 & 52.4 & 9.97 & 214.90 & & & \\
\hline \multirow{2}{*}{ MOTIV } & ext & 182 & 119 & 122.1 & 20.69 & 203.14 & \multirow{2}{*}{20318} & \multirow{2}{*}{-0.23} & \multirow{2}{*}{0.003} \\
\hline & int & 267 & 127 & 127.5 & 18.46 & 239.90 & & & \\
\hline
\end{tabular}

Source: Own work

Table 7. Direction of explanation of successes and criterion variables

\begin{tabular}{|c|c|c|c|c|c|c|c|c|c|}
\hline variable & $\begin{array}{c}\text { LOC } \\
\text { successes }\end{array}$ & $\mathrm{N}$ & $\mathrm{Me}$ & M & SD & $\begin{array}{c}\text { rank } \\
\text { average }\end{array}$ & $\mathrm{U}$ & $\mathrm{Z}$ & $\mathrm{p}$ \\
\hline \multirow{2}{*}{ DJGLS } & ext & 92 & 23 & 24.2 & 7.88 & 210.61 & \multirow{2}{*}{15098.5} & \multirow{2}{*}{-1.19} & \multirow{2}{*}{0.233} \\
\hline & int & 357 & 22 & 23.4 & 8.34 & 228.71 & & & \\
\hline \multirow{2}{*}{ GSES } & ext & 92 & 29 & 2.9 & 0.55 & 190.98 & \multirow{2}{*}{13292.5} & \multirow{2}{*}{-2.83} & \multirow{2}{*}{0.005} \\
\hline & int & 357 & 31 & 3.0 & 0.43 & 233.77 & & & \\
\hline \multirow{2}{*}{ SES } & ext & 92 & 30 & 2.8 & 0.59 & 205.47 & \multirow{2}{*}{14625.5} & \multirow{2}{*}{-1.62} & \multirow{2}{*}{0.105} \\
\hline & int & 357 & 31 & 2.9 & 0.60 & 230.03 & & & \\
\hline \multirow{2}{*}{ SBS } & ext & 92 & 57 & 2.8 & 0.50 & 281.84 & \multirow{2}{*}{11192.5} & \multirow{2}{*}{-4.71} & \multirow{2}{*}{$<0.001$} \\
\hline & int & 357 & 52 & 2.6 & 0.50 & 210.35 & & & \\
\hline \multirow{2}{*}{ MOTIV } & ext & 92 & 114 & 2.9 & 0.45 & 140.05 & \multirow{2}{*}{8606.5} & \multirow{2}{*}{-7.04} & \multirow{2}{*}{$<0.001$} \\
\hline & int & 357 & 128 & 2.9 & 0.45 & 246.89 & & & \\
\hline
\end{tabular}

Source: Own work 
Persons explaining failures internally feel significantly less lonely than persons explaining failures externally. Persons explaining failures by internal causes have a higher feeling of efficacy, however the difference as compared to persons explaining failures externally is not statistically significant. The analysis shows that persons assuming the internal direction of explanation of failures have significantly higher self-esteem than persons assuming the external direction. Higher helplessness is found in persons assuming external explanations, lower for persons assuming internal explanations. On the basis of the conducted research one could say, with an error probability of $0.3 \%$, that persons taking responsibility for their failures are more motivated.

Persons explaining successes externally are much less satisfied with their relations, however, the differences are not statistically significant. An analogous relation is found for self-esteem. With respect to the feeling of self-efficacy this difference is highly significant - persons ascribing successes to themselves feel much more efficient than those who do not do it. The same direction is taken by the difference between persons explaining successes differently - much more helpless are those that relinquish control to the outside. Additionally, persons who ascribe to themselves their successes are significantly more motivated than those who do not do it.

The above relations align with expectations.

\section{Summary}

To construct a tool to study the locus of control for school events should be useful in the daily work of a paedagogue allowing a swift evaluation of the LOC in school situations. In relation to this, alarming is the high proportion (11\%) of the persons studied who did not fill in the scale correctly. Even more so as this does not apply to the remaining scales used for testing validity. This can be due to the fact that the scale has an atypical structure or that they are found towards the end of the tool (reduction in respondent engagement). This, however, requires further study.

The advantages of the tool include the fact that it applies exclusively to school situations, is suitable for the age group of 17-19 years and is short, hence it can be easily used for the efficient diagnosis of student convictions.

The reliability of the tool as a whole as well as of the failure scale is sufficient. The measurement precision of the success scale fares worse. And even if this imperfection is not found only for the constructed scale (low reliability of this subscale also applies to other tools to measure the LOC), however, work must be continued on perfecting the scale. 
Persons taking over responsibility for failures themselves are much more satisfied with interpersonal relations, have a higher self-esteem, feel less helpless and more motivated, and the persons who ascribe successes to themselves believe that they are much more efficient, less helpless and more motivated. On the basis of the above analysis, one can hence say that the indicated relations aligned with expectations, however, not all of them seemed statistically significant.

Hence, one can conclude that the tool is valid, however, due to the psychometric parameters - it needs further development. The mode of providing answers must be simplified so that youths of all social groups, attending all kinds of schools, would understand its structure and be able to correctly fill it in; certain questions and answers must also be described with greater precision, in particular in the success scale.

\section{Bibliography}

Abramson L.Y. et al. (1978), Learned Helplessness in Humans: Critique and Reformulation. "Journal of Abnormal Psychology", no. 1, pp. 49-74, DOI http://dx.doi.org/10.1037/0021-843X.87.1.49

Alloy L.B. et al. (1984), Attributional Style and Generality of Learned Helplessness. "Journal of Personality and Social Psychology", no. 3, pp. 681-687, DOI: http://dx.doi.org/10.1037/00223514.46.3.681

American Psychological Association (2007), "Standardy dla testów stosowanych w psychologii i pedagogice", transl. by E. Hornowska. Gdańsk

Bandura A. (1977), Self-efficacy: Toward a Unifying Theory of Behavioral Change. "Psychological Review", no. 2, pp. 191-215, DOI: http://dx.doi.org/10.1037/0033-295X.84.2.191

Baumeister R.F. et al. (2003), Does High Self-Esteem Cause Better Performance, Interpersonal Success, Happiness, Or Healthier Lifestyles?. "Psychological Science in the Public Interest (Wiley-Blackwell)”, no. 4/1, pp. 1-44, DOI: http://dx.doi.org/10.1111/1529-1006.01431

Brzeziński J. (2004) Metodologia badań psychologicznych. Warszawa

Ciżkowicz B. (1999) Motywacja do uczenia się statystyki. Bydgoszcz

Ciżkowicz B. (2009) Wyuczona bezradność młodzieży. Bydgoszcz

Crandall V. et al. (1965), Children's Beliefs In Their Own Control Of Reinforcements In Inteuectual-Academic Achievement Situations. "Child Development", no. 1, pp. 91-109, DOI: http://dx.doi. org/10.1111/j.1467-8624.1965.tb05285.x

Drwal R.Ł. (1978) Poczucie kontroli jako wymiar osobowości-podstawy teoretyczne, techniki badawcze i wyniki badań. [in:] L. Wołoszynowa, (ed.), Materiały do nauczania psychologii, series III, vol. 3, pp. 307-345. Warszawa

Drwal R.Ł. (1995) Adaptacja kwestionariuszy osobowości: wybrane zagadnienia i techniki. Warszawa Dykstra P.A. et al. (2011), Cross-National Differences In Older Adult Loneliness. "The Journal Of Psychology", no. 146(1-2), pp. 201-228, DOI: http://dx.doi.org/10.1080/00223980.2011.631612 Dzwonkowska I. et al. (2007), Skala samooceny SES Morrisa Rosenberga - polska adaptacja metody, "Psychologia Społeczna", no. 02 (04), pp. 164-176.

Forsterling F. (2005) Atrybucje. Podstawowe teorie, badania i zastosowanie. transl. by J. Radzicki. Gdańsk 
Grygiel P. et al. (2013), Validating the Polish adaptation of the 11-item De Jong Gierveld Loneliness Scale. "European Journal of Psychological Assessment", no. 29(2), pp. 129-139, DOI: https://doi. org/10.1027/1015-5759/a000130

Hojat M. (1982), Loneliness As A Function OfSelected Personality Variables. “Journal of Clinical Psychology”, no. 38, pp. 137-141, DOI: http://dx.doi.org/10.1002/1097-4679(198201)38:1\%3C137::AID-JCLP2270380122\%3E3.0.CO;2-2

Juczyński Z. (2001) Narzędzia pomiaru w promocji i psychologii zdrowia. Warszawa

Klein J.; Wasserstein-Warnet M. (2000), Predictive Validity of the Locus of Control Test in Selection of School Administrators. "Journal of Educational Administration", no. 38/1, pp. 7-24, DOI: http://dx.doi.org/10.1108/09578230010310957

Kofta M. (2001), Poczucie kontroli, złudzenia na temat siebie, a adaptacja psychologiczna, [in:] Złudzenia, które pozwalają żyć, ed. by M. Kofta, T. Szustrowa, Warszawa

Krasowicz G., Kurzyp-Wojnarska A. (1990) Kwestionariusz do Badania Poczucia Kontroli. Podręcznik. Warszawa

Krasowicz-Kupis G., Wojnarska A. (2017) Kwestionariusz do Badania Poczucia Kontroli wersja zrewidowana. Warszawa

Maqsud M. (1980), The Relationship Of Sense Of Powerlessness of Antisocial Beahavior And School Achievement. "The Journal of Psychology", no. 105, pp. 147-150, DOI: http://dx.doi.org/10.108 0/00223980.1980.9915143

Meier S.F., Seligman M. (1976), Learned Helplessness: Theory and Evidence. "Journal of Experimental Psychology: General”, no. 1, pp. 3-46, DOI: http://dx.doi.org/10.1037/0096-3445.105.1.3

Niemierko B. (1999) Pomiar wyników kształcenia. Warszawa

Nowicki S. Jr, Strickland B.R. (1973), A Locus Of Control Scale For Children. "Journal of Consulting and Clinical Psychology", no. 1, pp. 148-154, DOI: http://dx.doi.org/10.1037/h0033978

Organization for Economic Co-operation and Development 2008. Education at a Glance.

O'Leary M.R. et al. (1977), Perceived Locus OfControl, Experienced Control, And Depression: A Trait Description Of The Learned Helplessness Model Of Depression. "Journal of Clinical Psychology", no. 33, pp. 164-168, DOI: http://dx.doi.org/10.1002/1097-4679(197701)33:1+\%3C164::AID-JCLP2270330136\%3E3.0.CO;2-O

Rotter J.B. (1966), Generalized Expectancies For Internal versus External control Of Reinforcement. "Psychological Monographs: General and Applied", no. 609, pp. 1-28, DOI: http://dx.doi. org/10.1037/h0092976

Skinner E.A, Zimmer-Gembeck M.J, Connell J.P, Eccles J.S, Wellborn J.G (1998), Individual Differences and the Development of Perceived Control. "Monographs of the Society for Research in Child Development”, vol. 63, no. 2/3, DOI: http://dx.doi.org/10.2307/1166220

Schwarzer R. (1998), General Perceived Self-Efficacy in 14 Cultures, available at: http://userpage.fu-berlin.de/health/world14.htm (access on 03.07.2017.)

Weiner B. (1985), An Attributional Theory of Achievement Motivation and Emotion. "Psychological Review”, no. 4, pp. 548-573, DOI: http://dx.doi.org/10.1037/0033-295X.92.4.548

Wong P.T.P., Weiner B. (1981), When Peopple Ask "Why" Questions And The Heuristics Of Attributional Search. "Journal of Personality and Social Psychology", no. 4, pp. 650-663, DOI: http:// dx.doi.org/10.1037/0022-3514.40.4.650

Zakrzewska M. (1994) Analiza czynnikowa w budowaniu i sprawdzaniu modeli psychologicznych. Poznań 